Article

\title{
Antisense-RNA-Mediated Gene Downregulation in Clostridium pasteurianum
}

\author{
Michael E. Pyne ${ }^{1, \dagger}$, Murray Moo-Young ${ }^{1}$, Duane A. Chung ${ }^{1,2, *}$ and C. Perry Chou ${ }^{1, *}$ \\ 1 Department of Chemical Engineering, University of Waterloo, Waterloo, ON N2L 3G1, Canada; \\ E-Mails: mpyne@uwaterloo.ca (M.E.P.); mooyoung@uwaterloo.ca (M.M.-Y.) \\ 2 Algaeneers Inc., Hamilton, ON L8N 3Z5, Canada \\ $\dagger$ Present address: Department of Biology and Centre for Structural and Functional Genomics, \\ Concordia University, Montréal, QC H4B 1R6, Canada \\ * Authors to whom correspondence should be addressed; E-Mails: cpchou@uwaterloo.ca (C.P.C.); \\ duane.chung@uwaterloo.ca (D.A.C.); Tel.: 519-888-4567 (ext. 33310) (C.P.C.).
}

Academic Editor: George N. Bennett

Received: 22 September 2015 / Accepted: 2 December 2015 / Published: 9 December 2015

Abstract: Clostridium pasteurianum is receiving growing attention for its unique metabolic properties, particularly its ability to convert waste glycerol and glycerol-rich byproducts into butanol, a prospective biofuel. Genetic tool development and whole genome sequencing have recently been investigated to advance the genetic tractability of this potential industrial host. Nevertheless, methodologies for tuning gene expression through plasmid-borne expression and chromosomal gene downregulation are still absent. Here we demonstrate plasmid-borne heterologous gene expression and gene knockdown using antisense RNA in C. pasteurianum. We first employed a common thermophilic $\beta$-galactosidase (lacZ) gene reporter system from Thermoanaerobacterium thermosulfurogenes to characterize two promoters involved in the central fermentative metabolism of $C$. pasteurianum. Due to a higher level of constitutive lac $Z$ expression compared to the ferredoxin gene $(f d x)$ promoter, the thiolase $(t h l)$ promoter was selected to drive expression of asRNA. Expression of a lac $Z$ asRNA resulted in 52\%-58\% downregulation of $\beta$-galactosidase activity compared to the control strain throughout the duration of culture growth. Subsequent implementation of our asRNA approach for downregulation of the native hydrogenase I gene (hydA) in C. pasteurianum resulted in altered end product distribution, characterized by an increase in production of reduced metabolites, particularly butyrate (40\% increase) and ethanol $(25 \%$ increase). Knockdown of hydA was also accompanied by increased acetate formation and 
lower levels of 1,3-propanediol, signifying a dramatic shift in cellular metabolism in response to inhibition of the hydrogenase enzyme. The methodologies described herein for plasmid-based heterologous gene expression and antisense-RNA-mediated gene knockdown should promote rational metabolic engineering of $C$. pasteurianum for enhanced production of butanol as a prospective biofuel.

Keywords: antisense RNA; biofuels; Clostridium; gene reporter; genetic engineering; glycerol; gene knockdown; metabolic engineering

\section{Introduction}

Clostridium pasteurianum is a strictly anaerobic, Gram-positive, spore-forming bacterium that has received growing biotechnological attention for its capacity to ferment low-value waste feedstocks, particularly crude glycerol, to commodity chemicals and biofuels [1-3]. C. pasteurianum is the only known organism capable of converting glycerol to butanol [4], an attractive biofuel that is superior to ethanol [5-7]. Cheap crude glycerol is currently available in abundance as a result of the tremendous growth experienced by global biodiesel and bioethanol industries in recent years [8,9]. Biodiesel production yields $10 \%(w / w)$ crude glycerol, while up to 20 liters of glycerol-rich thin stillage can result from the production of only 1 liter of bioethanol [10]. In 2007, global biodiesel production capacity from a total of 119 countries was estimated at 51 billion liters [11], leading to a plummet in the price of crude glycerol to approximately $\$ 0.05 / \mathrm{lb}$ [8]. Consequently, C. pasteurianum has become an attractive prospective industrial host for the production of butanol from abundant and renewable waste glycerol [3]. Up to now, few genetic tools have been developed for metabolic engineering of this important bacterium. We recently developed a high-efficiency electrotransformation procedure for gene transfer to C. pasteurianum [12], in addition to an intron-based method of chromosomal gene disruption [13]. Several genome sequencing projects are underway [14-16], including two completed genome sequences [17,18] and one genomic analysis report [19]. Collectively these developments serve as the initial steps toward extensive metabolic engineering of this unique species [20].

A fundamental facet of metabolic engineering is the ability to decrease the expression of genes involved in competing metabolic pathways through the use of gene knockdown and knockout techniques [21]. Gene knockouts cause complete inhibition of gene expression and, therefore, often lead to lethal phenotypes, particularly for genes involved in central metabolic pathways [22]. For example, disruption of the hydrogenase or thiolase genes [23] in C. acetobutylicum is presumed to result in cell death, thus placing significant constraints on rational metabolic engineering strategies employing gene knockout. Antisense-RNA-mediated gene downregulation, on the other hand, is a more refined approach for limiting expression of native genes and metabolic pathways, as production of the target protein is still permitted, though at a substantially decreased level [24,25]. For organisms that carry out highly branched and complex fermentations, such as C. pasteurianum [5,26], metabolic engineering is a very useful tool for limiting or entirely abolishing carbon and electron fluxes through competing pathways [20]. Although C. pasteurianum naturally produces appreciable quantities of butanol (up to $17 \mathrm{~g} \cdot \mathrm{L}^{-1}$ [27]) from glycerol, 1,3-propanediol also accumulates in the culture medium, thus limiting flux through the 
butanol biosynthetic pathway. Gene downregulation is expected to be of great value to metabolic engineering of $C$. pasteurianum [3], as current understanding of glycerol catabolism in Clostridium dictates that disruption of the reductive 1,3-propanediol pathway will uncouple biomass formation and glycerol dissimilation [4], leading to inability to metabolize glycerol and subsequent cell death. Therefore, attenuation of competing pathways via antisense-RNA-mediated gene knockdown is a viable option for increasing butanol titer from fermentation of glycerol by $C$. pasteurianum.

Antisense RNAs are designed to possess partial or complete complementarity to a target mRNA, leading to base-pairing and degradation of the resulting RNA duplex prior to mRNA translation [24,28,29]. Alternatively, it has been proposed that mRNA-asRNA complexes sterically block translational machinery, resulting in reduced levels of the target protein [24]. This strategy has been employed in several clostridial species, including C. acetobutylicum [24,25,30], C. cellulolyticum [31], and C. saccharoperbutylacetonicum [32], for downregulation of competing metabolic pathways, including butyrate and acetone formation pathways, to enhance butanol titers, selectivity, and tolerance $[24,25,30,31,33,34]$. Degree of gene downregulation has been shown to vary, for example between $44 \%$ and $92 \%$ in one report [25], and is commonly quantified by measuring enzyme activity or production of protein target via Western blot analysis. Downregulation can also be finely tuned by selection of the promoter driving transcription of the asRNA, where stronger promoters presumably generate more asRNA product, leading to a greater degree of downregulation [24]. Promoters utilized in successful asRNA approaches include ones from genes involved in central carbon metabolism, such as phosphotransbutyrylase $(p t b)$ and thiolase $(t h l)$ [35], as well as butanol dehydrogenase $(b d h)$ [32].

In this report, we engineered $C$. pasteurianum through manipulation of gene expression. We employed a common clostridial gene reporter system based on the Thermoanaerobacterium thermosulfurogenes $\beta$-galactosidase gene (lacZ) [35] to assess the relative strength of two gene promoters involved in the central fermentative metabolism of $C$. pasteurianum. We then selected the native $C$. pasteurianum thiolase promoter to drive transcription of asRNA targeted to our lac $Z$ reporter gene. To assess the efficacy of gene knockdown in C. pasteurianum, we targeted the primary hydrogenase gene (hydA) for downregulation using our devised asRNA approach. Collectively, we demonstrate that asRNA gene knockdown and plasmid-based heterologous gene expression, along with a complete genome sequence $[18,19]$ and previously developed genetic tools $[12,13]$, should promote the feasibility of metabolic engineering and strain optimization of C. pasteurianum.

\section{Experimental Section}

\subsection{Bacterial Strains, Cultivation Conditions, and Electrotransformation}

Bacterial strains utilized in this work are listed in Table 1. C. pasteurianum ATCC 6013 was cultivated in $2 \times$ YTG medium (per liter: $16 \mathrm{~g}$ tryptone, $10 \mathrm{~g}$ yeast extract, $5 \mathrm{~g}$ glucose, $4 \mathrm{~g}$ sodium chloride, $\mathrm{pH}$ 6.2) and spores were maintained on solidified $2 \times \mathrm{YTG}$ medium containing $12 \mathrm{~g} \cdot \mathrm{L}^{-1}$ agar, as described previously [12]. Vegetative cultures were prepared by suspending and heat shocking a sporulated colony at $80{ }^{\circ} \mathrm{C}$ for $10 \mathrm{~min}$. Recombinant $C$. pasteurianum strains were selected using $10 \mu \mathrm{g} \cdot \mathrm{mL}^{-1}$ thiamphenicol or $6 \mu \mathrm{g} \cdot \mathrm{mL}^{-1}$ clarithromycin. Electrotransformation of C. pasteurianum was performed according to a previous report [12]. 
Table 1. Strains, plasmids, and oligonucleotides employed in this study.

\begin{tabular}{|c|c|c|}
\hline Strains or Plasmids & Relevant Characteristics & $\begin{array}{l}\text { Source or } \\
\text { Reference }\end{array}$ \\
\hline \multicolumn{3}{|l|}{ Strains } \\
\hline $\begin{array}{l}\text { Escherichia coli } \\
\text { DH5 } \alpha\end{array}$ & $\begin{array}{l}\mathrm{F}^{-} \text {endA1 glnV44 thi-1 recA1 relA1 } \\
\text { gyrA96 deoR nup } G \text { } \varphi 0 \text { dlacZAM15 } \\
\Delta(\text { lacZYA-argF }) U 169, \text { hsdR } 17\left(r_{K}^{-} m_{K}^{+}\right), \lambda^{-}\end{array}$ & Lab stock \\
\hline $\begin{array}{l}\text { Escherichia coli } \\
\text { ER1821 }\end{array}$ & $\begin{array}{l}\mathrm{F}^{-} \text {endA1 glnV44 thi-1 relA1? e14 }\left(\mathrm{mcr}^{-}\right) \\
\text {rfbD1? spoT1? } \Delta(\mathrm{mcrC}-\mathrm{mrr}) 114: \because \mathrm{S} 10\end{array}$ & $\begin{array}{l}\text { Lab stock; } \\
\text { New England Biolabs }\end{array}$ \\
\hline $\begin{array}{l}\text { Clostridium pasteurianum } \\
\text { ATCC } 6013\end{array}$ & Wild-type & $\begin{array}{l}\text { American type } \\
\text { culture collection }\end{array}$ \\
\hline \multicolumn{3}{|l|}{ Plasmids } \\
\hline pFnuDIIMKn & $\begin{array}{l}\text { E. coli vector expressing the M.FnuDII } \\
\text { methyltransferase for plasmid methylation } \\
\text { prior to electrotransformation of } \\
\text { C. pasteurianum }\left(\mathrm{Kn}^{\mathrm{R}} ; \text { p } 15 \mathrm{~A} \text { ori }\right)\end{array}$ & {$[12]$} \\
\hline pHT3 & $\begin{array}{l}\text { Promoterless E. coli-C. pasteurianum } \\
\beta \text {-galactosidase gene expression reporter } \\
\text { vector }\left(\mathrm{Ap}^{\mathrm{R}} ; \text { ColE1 ori; } \mathrm{Em}^{\mathrm{R}} \text {; pIM13 ori) }\right.\end{array}$ & {$[35]$} \\
\hline pMTL85141 & $\begin{array}{l}\text { E. coli-C. pasteurianum shuttle vector } \\
\text { (ColE1 ori; } \mathrm{Tm}^{\mathrm{R}} \text {; pIM13 ori) }\end{array}$ & {$[36]$} \\
\hline pSY6catP & $\begin{array}{l}\text { E. coli-Clostridium group II intron expression } \\
\text { vector }\left(\mathrm{Ap}^{\mathrm{R}} ; \mathrm{ColE} 1 \text { ori; } \mathrm{Tm}^{\mathrm{R}} ; \mathrm{pIM} 13 \text { ori }\right)\end{array}$ & {$[12]$} \\
\hline pHT3catP & Thiamphenicol-resistant derivative of pHT3 & This study; [37] \\
\hline pHT3catP-fdx & $\begin{array}{l}\text { Derived by transcriptionally fusing the } C \text {. pasteurianum } \\
f d x \text { promoter with the lac } Z \text { gene of } \mathrm{pHT} \text { catP }\end{array}$ & This study \\
\hline pHT3catP-thl & $\begin{array}{l}\text { Derived by transcriptionally fusing the } C \text {. pasteurianum } \\
\text { thl promoter with the } l a c Z \text { gene of } \mathrm{pHT} 3 \text { catP }\end{array}$ & This study \\
\hline pHTaslacZ110 & $\begin{array}{l}\text { Vector expressing a } 110 \mathrm{nt} l a c Z \text { asRNA from } \\
\text { the } C \text {. pasteurianum thl promoter }\end{array}$ & This study \\
\hline pHTashydA & $\begin{array}{l}\text { Vector expressing a } 175 \mathrm{nt} \text { hydA asRNA from } \\
\text { the } C \text {. pasteurianum thl promoter }\end{array}$ & This study \\
\hline Oligonucleotide & \multicolumn{2}{|l|}{ Sequence $\left(5^{\prime}-3^{\prime}\right) *$} \\
\hline Pfdx.NarI.S & \multicolumn{2}{|c|}{ CAGAACGGCGCCGAAGATATAAGAAAAAGACTCCCAAAGG } \\
\hline Pfdx.XmaI.AS & \multicolumn{2}{|c|}{ ATCATACCCGGGCCATAACTTATTGTATCATGTTTTTAAAC } \\
\hline Pthl.NarI.S & \multicolumn{2}{|c|}{ CTGTAGGCGCCGATATAGTCTATAAGCATTTAGATGGAGTTAG } \\
\hline Pthl.XmaI.AS & \multicolumn{2}{|c|}{ AAATACCCGGGTCGATTGTTATTTAATTCACAATTTAATTATAACC } \\
\hline
\end{tabular}

\subsection{DNA Isolation, Manipulation, and Plasmid Construction}

Plasmids and oligonucleotides utilized in this work are shown in Table 1. Oligonucleotides were synthesized by Integrated DNA Technologies (IDT; Coralville, IA, USA) at the 25 nanomole scale using standard desalting. Restriction endonucleases, Quick Ligation Kit, Standard Taq DNA Polymerase, and Phusion DNA Polymerase were purchased from New England Biolabs (Ipswich, MA, USA). Molecular biology kits for purification of plasmid DNA, PCR products, and gel purified DNA and custom gene 
synthesis were purchased from Bio Basic Inc. (Markham, ON, USA). Recombinant DNA methods were performed according to standard procedures [38]. Total genomic DNA was isolated from C. pasteurianum as previously described [13].

A thiamphenicol derivative of pHT3 [35], named pHT3catP [37], was constructed by subcloning a 1314 bp ClaI + SacI restriction fragment of pSY6catP [12] containing a thiamphenicol-resistance cassette into the corresponding restriction sites of the erythromycin-resistance determinant of pHT3. Transcriptional promoter fusions with $l a c Z$ in $\mathrm{pHT} 3$ catP were prepared by amplifying putative $f d x$ and thl promoter regions from $C$. pasteurianum total genomic DNA using primer pairs Pfdx.NarI.S + Pfdx.XmaI.AS and Pthl.NarI.S + Pthl.XmaI.AS, respectively. The resulting $565 \mathrm{bp}(f d x)$ and $511 \mathrm{bp}(t h l)$ PCR products were digested with NarI + XmaI and ligated into the corresponding sites of pHT3catP to generate pHT3catP-fdx and pHT3catP-thl, respectively. To construct plasmid pHTaslacZ110, a lacZ asRNA expression cassette containing the $C$. pasteurianum thl promoter, lac $Z$ asRNA, and C. pasteurianum $f d x$ transcriptional terminator was obtained as a custom AhdI- and BstAPI-flanked gene synthesis fragment. The resulting 517 bp fragment was digested with AhdI + BstAPI and inserted into the corresponding restriction sites of $\mathrm{pHT} 3 \mathrm{catP}-\mathrm{thl}$. Plasmid pHTashydA was constructed by obtaining a 276 bp BamHI- and BstXI-flanked custom gene synthesis product possessing a $175 \mathrm{nt}$ hydA asRNA upstream of the $C$. pasteurianum $f d x$ transcriptional terminator. Antisense RNA was designed to target the RBS and 164 nt of the 5' hydA coding region. The resulting synthetic product was digested with BamHI + BstXI and ligated into the corresponding sites of pHT3catP-thl for transcriptional fusion of the hydA asRNA with the C. pasteurianum thl promoter.

\subsection{Strain Cultivation}

$\beta$-Galactosidase expression and enzymatic assay were performed as previously described $[35,39]$, with slight modifications. For expression of recombinant $C$. pasteurianum ATCC 6013 harboring pHT3catP, pHT3catP-fdx, pHT3catP-thl, or pHTaslacZ110, $45 \mathrm{~mL}$ samples were removed from each flask in duplicate every $3-5 \mathrm{~h}$ starting at an $\mathrm{A} 600$ of $\sim 0.5$. Cells were harvested from cultures by centrifugation at $10,000 \times g$ for $10 \mathrm{~min}$ at $4{ }^{\circ} \mathrm{C}$, and the resulting cell pellets were stored at $-80{ }^{\circ} \mathrm{C}$. Cell pellets were thawed on ice, resuspended in Z buffer to an OD 600 of 20 in a minimum volume of $1 \mathrm{~mL}$, and lysed by incubation in the presence of $1 \mathrm{mg} / \mathrm{mL}$ lysozyme for $1 \mathrm{~h}$ at $37^{\circ} \mathrm{C}$, unless specified otherwise. One $\mathrm{mL}$ of the resulting lysates was cleared of cell debris by centrifugation at $16,000 \times \mathrm{g}$ for $15 \mathrm{~min}$ at $4{ }^{\circ} \mathrm{C}$ and the supernatant was heated in a $60{ }^{\circ} \mathrm{C}$ water bath for $30 \mathrm{~min}$. Denatured heat-labile proteins were cleared by centrifugation at $16,000 \times \mathrm{g}$ for $30 \mathrm{~min}$ at $4{ }^{\circ} \mathrm{C}$. Supernatants were stored at $4{ }^{\circ} \mathrm{C}$ prior to enzymatic assays.

Shake flask cultures expressing hydA asRNA (pHTashydA) or the control plasmid (pMTL85141) were cultivated in $50 \mathrm{~mL}$ of semi-defined medium [4,40] containing per liter: $0.5 \mathrm{~g} \mathrm{KH}_{2} \mathrm{PO}_{4}, 0.5 \mathrm{~g}$

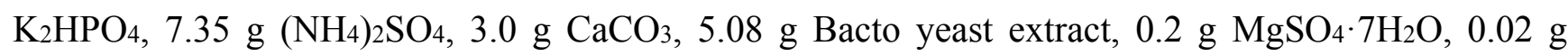
$\mathrm{CaCl}_{2} \cdot 2 \mathrm{H}_{2} \mathrm{O}, 0.06 \mathrm{~g} \mathrm{FeSO}_{4} \cdot 7 \mathrm{H}_{2} \mathrm{O}, 1 \mathrm{mg}$ resazurin, and $2 \mathrm{~mL}$ trace element solution SL 7 . The initial $\mathrm{pH}$ of the medium was adjusted to 6.0 prior to sterilization. Glycerol was sterilized separately as a stock solution and added to culture flasks to attain a final concentration of $50 \mathrm{~g} \mathrm{~L}^{-1}$. Cysteine- $\mathrm{HCl}\left(0.5 \mathrm{~g} \mathrm{~L}^{-1}\right)$ was used to reduce growth medium. Cultures were incubated anaerobically with slight agitation (150 rpm) for 40-50 h. Seed cultures were prepared in 2×YTG medium from sporulated heat-shocked colonies. 


\subsection{Analytical Methods}

Cell growth was quantified spectrophotometrically by measuring culture optical density at $600 \mathrm{~nm}$ $\left(\mathrm{OD}_{600}\right)$. $\beta$-Galactosidase activity was assayed as described [35] at $60{ }^{\circ} \mathrm{C}$ by measuring optical density at $420 \mathrm{~nm}\left(\mathrm{OD}_{420}\right)$ following development of yellow color resulting from cleavage of ortho-nitrophenyl- $\beta$-galactoside (ONPG) to orthonitrophenol. Specific $\beta$-galactosidase activity is expressed in Miller units [39].

Shake flask culture supernatants were analyzed for metabolite production by LC-10AT HPLC analysis (Shimadzu, Kyoto, Japan) containing a RID-10A refractive index detector (Shimadzu, Kyoto, Japan) and Aminex HPX-87H column (Bio-Rad Laboratories, Richmond, CA, USA). The mobile phase consisted of $0.005 \mathrm{M} \mathrm{H}_{2} \mathrm{SO}_{4}(\mathrm{pH} 2.0)$ at a flow rate of $0.6 \mathrm{~mL} \cdot \mathrm{min}^{-1}$. Data processing was performed using Clarity Lite (DataApex, Prague, Czech Republic). Metabolite titers reported represent the average of two biological replicates.

\section{Results}

A modified thiamphenicol-selectable reporter system, pHT3catP, containing a thermophilic $\beta$-galactosidase gene, lacZ [35], was utilized to assess the function of two promoters involved in the central metabolism of $C$. pasteurianum. Putative promoter regions from the native ferredoxin $(f d x)$ [41] and thiolase ( $t h l)$ [42] genes of $C$. pasteurianum were cloned upstream of $l a c Z$ in pHT3catP to generate transcriptional fusions ( $\mathrm{P}_{\mathrm{fdx}}-l a c Z$ and $\mathrm{P}_{\text {thl }}-l a c Z$, respectively). The respective plasmids, pHT3catP-fdx and $\mathrm{pHT} 3 \mathrm{catP}-\mathrm{thl}$, in addition to the promoterless $\mathrm{pHT} 3 \mathrm{catP}$ control vector, were electrotransformed to C. pasteurianum ATCC 6013 and the resulting recombinant strains were used to assess expression of lacZ (Figure 1). The control plasmid pHT3catP failed to generate $\beta$-galactosidase activity ( $<8 \mathrm{MU}$ ) throughout the duration of cell growth. Conversely, both pHT3catP-fdx and pHT3catP-thl yielded significant $\beta$-galactosidase activity. Specifically, the $\mathrm{P}_{\mathrm{fdx}}-l a c Z$ construct generated a lower maximal

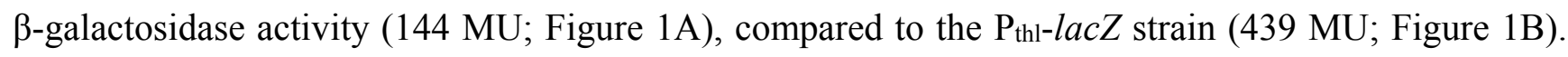
Although the $f d x$ promoter has been widely used for gene expression in a range of clostridia $[43,44]$, we opted for the stronger $t h l$ promoter for subsequent expression of asRNA in C. pasteurianum.

A.

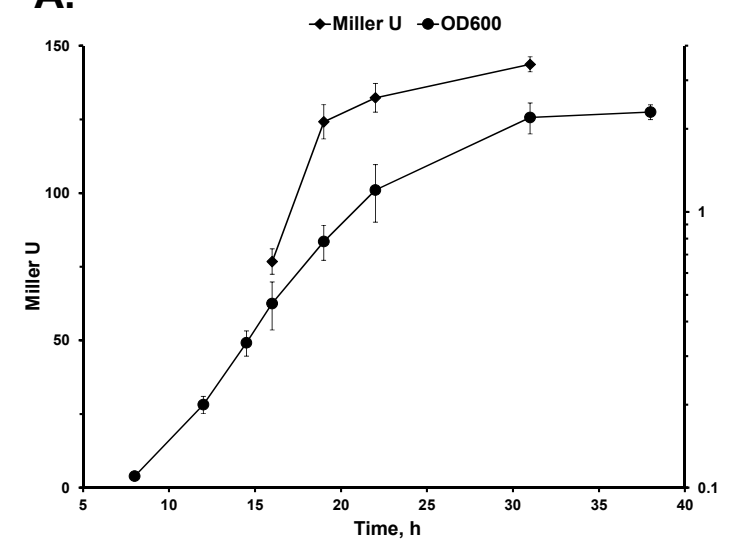

B.

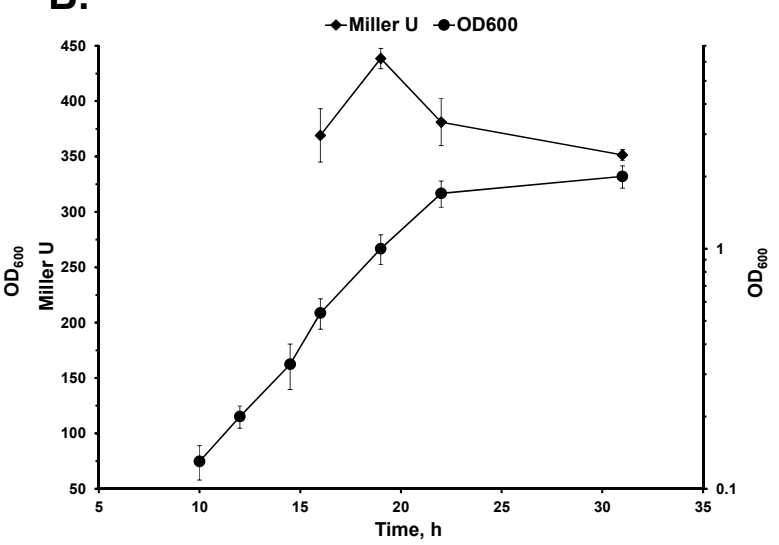

Figure 1. Time course $\beta$-galactosidase activities of static flask cultures harboring lacZ transcriptional fusion constructs. (A) $\mathrm{P}_{\mathrm{fdx}}-l a c Z$ cassette (pHT3catP-fdx); (B) $\mathrm{P}_{\text {thl-lacZ }}$ cassette (pHT3catP-thl). 
To assess the efficacy of asRNA-mediated gene downregulation in C. pasteurianum, we again utilized thermophilic $l a c Z$ as a reporter gene. An asRNA cassette was designed by placing a $110 \mathrm{nt}$ lacZ asRNA under transcriptional control of the $t h l$ promoter $\left(\mathrm{P}_{\text {thl-aslac } Z 110)}\right.$ and a transcriptional terminator derived from the $C$. pasteurianum $f d x$ gene immediately downstream of the asRNA sequence. The $110 \mathrm{nt} l a c Z$ asRNA was designed to target $66 \mathrm{bp}$ upstream of the initiation codon, including the ribosome binding

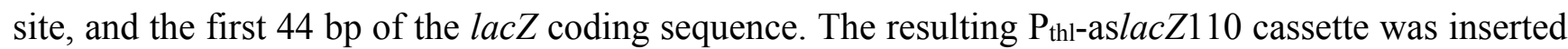
into plasmid pHT3catP-thl, generating pHTaslacZ110. In this configuration, the lacZ asRNA cassette

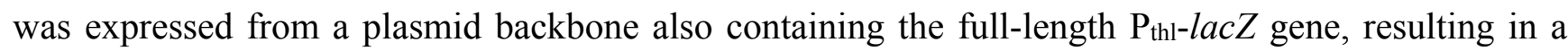
plasmid harboring two copies of the same thl promoter (Figure 2A). Following electrotransformation, recombinant $C$. pasteurianum strains respectively harboring pHT3catP, pHT3catP-thl, or pHTaslacZ110 were cultivated in parallel and cells were harvested and assayed for $\beta$-galactosidase activity at various

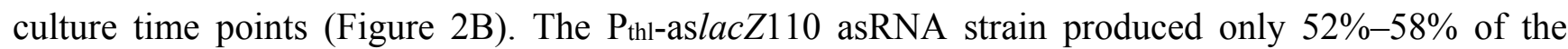

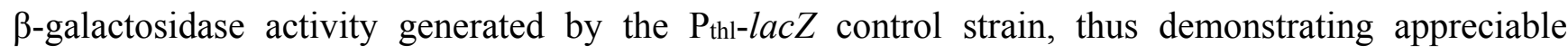
downregulation of plasmid-encoded lacZ.

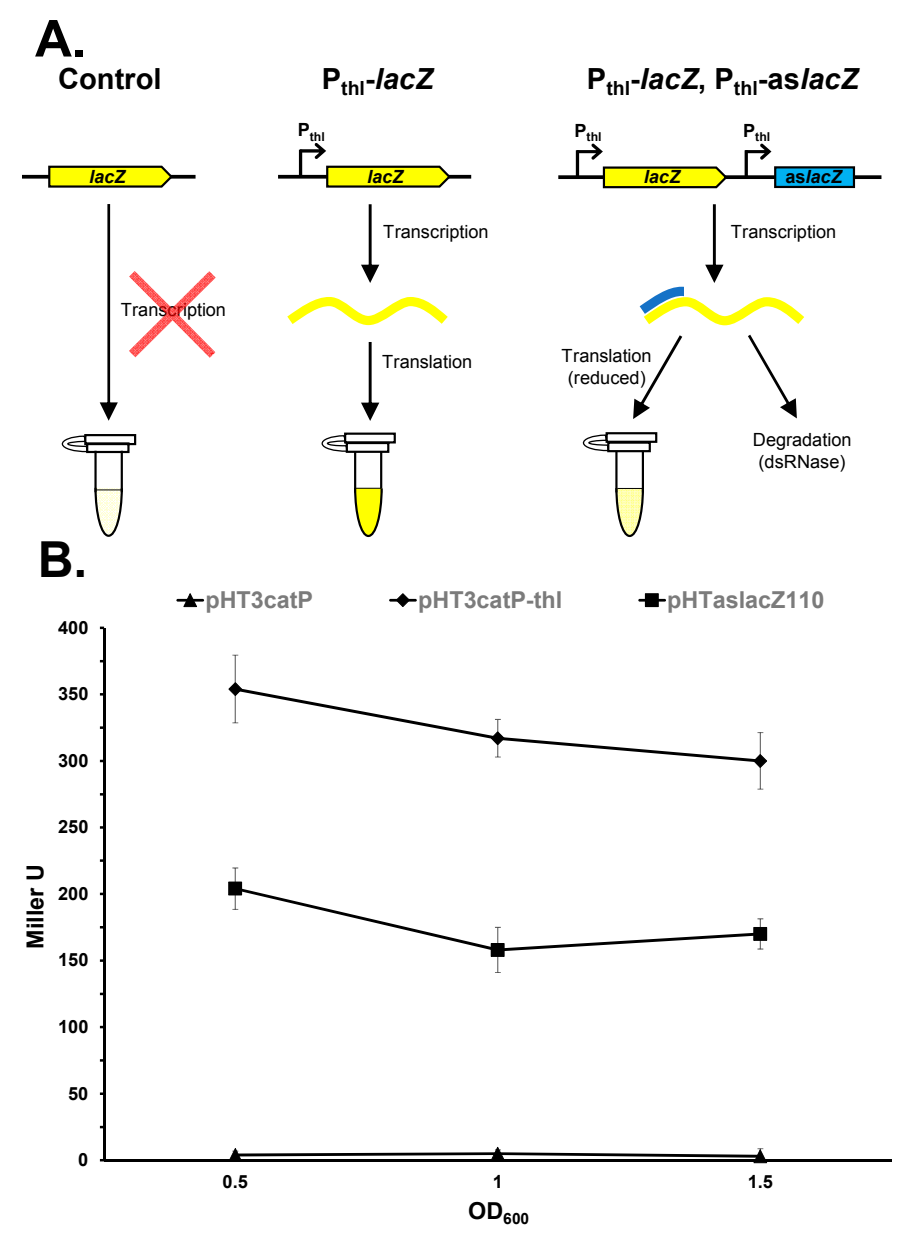

Figure 2. Antisense-RNA-mediated gene downregulation in C. pasteurianum. (A) Antisense RNA strategy and proposed mechanism of gene downregulation based on $\beta$-galactosidase enzymatic assay. dsRNase refers to putative host RNase(s) recognizing double-stranded RNA molecules; (B) $\beta$-Galactosidase activities of static flask cultures harboring promoterless lacZ plasmid pHT3catP, $\mathrm{P}_{\text {thl-lacZ }}$ plasmid $\mathrm{pHT} 3$ catP-thl, and $\mathrm{P}_{\text {thl-aslacZ110 antisense RNA }}$ plasmid pHTaslacZ110. 
Based on successful downregulation of heterologous lacZ using asRNA, we aimed to extend our approach to a native $C$. pasteurianum gene involved in the organism's central fermentative metabolism. Accordingly, we designed a $175 \mathrm{nt}$ asRNA cassette targeted to the $C$. pasteurianum hydrogenase I gene (hydA). The resulting plasmid (pHTashydA175), in addition to the control plasmid lacking asRNA (pMTL85141), were transferred to C. pasteurianum and shake flask cultivations were performed using a semi-defined growth medium containing $50 \mathrm{~g} \mathrm{~L}^{-1}$ glycerol. Compared to the control strain, the hydA asRNA strain produced markedly less gas, as evidenced from a reduced amount of bubbles and foam at the surface of shake flasks. This outcome is consistent with decreased hydrogen gas evolution resulting from hydrogenase inhibition. Cultures harboring pHTashydA175 also reached a higher final cell density and exhibited a shorter cultivation time (Table 2). End product analysis of cultures harboring pMTL85141 control plasmid and pHTashydA asRNA plasmid revealed dramatic differences in product distribution. The hydA asRNA strain produced enhanced levels of acetate (137\% increase), butyrate ( $40 \%$ increase), ethanol ( $25 \%$ increase) and, to a lesser extent, butanol (12\% increase) (Table 2). 1,3-Propanediol was the only metabolite that was produced at a lower level ( $43 \%$ decrease) following expression of asRNA relative to the control strain. Overall, hydA asRNA expression increased total acid production by $108 \%$, while total alcohol formation was largely unaffected.

Table 2. End product analysis of shake flask cultures harboring pMTL85141 and pHTashydA.

\begin{tabular}{|c|c|c|c|c|c|c|c|c|c|c|}
\hline \multirow[t]{2}{*}{ Strain } & \multirow{2}{*}{$\begin{array}{l}\text { Culture } \\
\text { time (h) }\end{array}$} & \multirow[t]{2}{*}{ OD $_{600}$} & \multicolumn{8}{|c|}{ Substrate and product titers $\left(\mathrm{g} \mathrm{L}^{-1}\right)$} \\
\hline & & & Glycerol & Acetate & Butyrate & Ethanol & Butanol & $\begin{array}{l}1,3- \\
\text { PDO }\end{array}$ & $\begin{array}{l}\text { Total } \\
\text { acids }\end{array}$ & $\begin{array}{c}\text { Total } \\
\text { alcohols }\end{array}$ \\
\hline $\begin{array}{c}\text { WT } \\
(\mathrm{pMTL85141)}\end{array}$ & 52.5 & $\begin{array}{c}7.6 \pm \\
0.4\end{array}$ & $\begin{array}{c}11.4 \pm \\
0.06\end{array}$ & $\begin{array}{c}0.38 \pm \\
0.0\end{array}$ & $\begin{array}{c}0.15 \pm \\
0.02\end{array}$ & $\begin{array}{l}1.6 \pm \\
0.04\end{array}$ & $\begin{array}{c}8.9 \pm \\
0.3\end{array}$ & $\begin{array}{c}3.3 \pm \\
0.3\end{array}$ & $\begin{array}{c}0.53 \pm \\
0.02\end{array}$ & $\begin{array}{c}13.8 \pm \\
0.05\end{array}$ \\
\hline $\begin{array}{c}\text { WT } \\
(\mathrm{pHTashydA})\end{array}$ & 43.0 & $\begin{array}{c}10.3 \pm \\
0.07\end{array}$ & $\begin{array}{c}12.3 \pm \\
0.1\end{array}$ & $\begin{array}{c}0.90 \pm \\
0.4\end{array}$ & $\begin{array}{c}0.21 \pm \\
0.0\end{array}$ & $\begin{array}{c}2.0 \pm \\
0.1\end{array}$ & $\begin{array}{c}10.0 \pm \\
0.0\end{array}$ & $\begin{array}{l}2.3 \pm \\
0.03\end{array}$ & $\begin{array}{c}1.1 \pm \\
0.4\end{array}$ & $\begin{array}{c}14.4 \pm \\
0.07\end{array}$ \\
\hline
\end{tabular}

\section{Discussion}

Fundamental genetic techniques to modulate host gene expression through either gene upregulation (i.e., overexpression) or downregulation (i.e., knockdown) have found widespread use within the clostridia for various strain construction applications [21]. Since a method of gene transfer has only recently been reported for $C$. pasteurianum [12], techniques to manipulate gene expression are lacking for this species. Here we demonstrate the utility of both plasmid-based heterologous gene expression and asRNA-mediated gene knockdown in C. pasteurianum.

By generating transcriptional fusions, gene reporter systems facilitate characterization of a range of host promoters, resulting in a diverse promoter library, ideally exhibiting a broad spectrum of expression strengths. Most frequently, strong constitutive promoters are desired to maximize expression of a target gene or metabolic pathway throughout the duration of culture growth [20]. To compare promoters and provide a quantitative means of assessing relative promoter strength in $C$. pasteurianum, we selected a thermophilic $\beta$-galactosidase gene reporter system [35], since it has found widespread use in the clostridia [20]. We selected promoters from the $C$. pasteurianum thl and $f d x$ genes, since the C. acetobutylicum thl gene promoter leads to high level constitutive gene expression [35] and the ferredoxin protein accounts for up to $2 \%$ of total soluble protein in growing cultures of C. pasteurianum [45]. 
We showed that the $C$. pasteurianum thl promoter generated roughly three-fold higher maximal $\beta$-galactosidase activity compared to the native $f d x$ promoter (Figure 1 ). A similar result was obtained using $C$. acetobutylicum, as the native $t h l$ promoter out-performed promoters from the $C$. acetobutylicum phosphotransbutyrylase $(p t b)$ and acetoacetate decarboxylase $(a d c)$ genes [35]. Thiolase, which catalyzes the transition from $\mathrm{C}_{2}$ to $\mathrm{C}_{4}$ intermediates in clostridial metabolism [5,26], would be expected to be expressed at a high level in both of these organisms, since the preferred products of glucose fermentation are butyrate $\left(\mathrm{C}_{4}\right)$ in the case of $C$. pasteurianum [46] and butyrate and butanol $\left(\mathrm{C}_{4}\right)$ in the case of C. acetobutylicum [5]. Although the thl promoter proved superior in C. pasteurianum, the C. pasteurianum $f d x$ promoter still produced appreciable $\beta$-galactosidase activity owing to ferredoxin's central role in clostridial fermentative metabolism. Further, the $C$. pasteurianum $f d x$ promoter has been shown to function in C. acetobutylicum and C. sporogenes [44], in addition to C. cellulolyticum [43,47] and E. coli [41].

In addition to promoter characterization, expression of lac $Z$ in this study exemplifies the first demonstration of quantifiable heterologous gene expression in C. pasteurianum. Accordingly, the thl and $f d x$ promoters, along with the associated pHT3 vector backbone, which is based on pIMP1 [48] and contains the commonly employed pIM13 Gram-positive replication module, together constitute the fundamental genetic components necessary for expressing heterologous genes and pathways in C. pasteurianum. In this context, the $t h l$ promoter is favored for applications demanding high-level gene expression, while the $f d x$ promoter could be better suited in instances where maximal levels of gene expression are not paramount or desirable. Further, although not investigated in this report, the vector elements required for heterologous gene expression can also be utilized to enhance expression of native C. pasteurianum chromosomal genes through plasmid-based gene overexpression. Both heterologous and homologous gene expression strategies are vital to producing superior host strains through metabolic engineering and strain optimization [20].

Based on time course studies of $\beta$-galactosidase activity (Figure 1), we selected the thl promoter to drive transcription of asRNA in C. pasteurianum (Figure 2A). Using this approach, we achieved greater than 50\% knockdown of lacZ at multiple time points throughout culture growth (Figure 2B), demonstrating that asRNA gene downregulation represents a viable option for controlling gene expression in C. pasteurianum. Since asRNA size and secondary structure are important design considerations [25] that were not investigated in this study, we advise the use of transcriptional terminators to avoid generation of superfluous non-homologous sequence at the $3^{\prime}$ end of asRNAs that may interfere with hybridization to target mRNAs. We also recommend testing multiple asRNAs in parallel for each knockdown target, as predicting asRNA effectiveness could prove challenging without assaying multiple designs.

The efficacy of our asRNA gene knockdown methodology was verified by targeting the primary hydrogenase gene (hydA) in C. pasteurianum. We observed a dramatic shift in end product distribution characterized by increased production of acids (acetate and butyrate) and ethanol (Table 2). Based on current models of clostridial metabolism, inhibition of the hydrogenase enzyme is expected to result in a buildup of reduced ferredoxin, which is subsequently utilized to drive reduction of $\mathrm{NAD}^{+}$to $\mathrm{NADH}$ by the ferredoxin:NAD ${ }^{+}$oxidoreductase enzyme. The NADH formed in this reaction is then employed for generation of reduced end products, such as ethanol and butanol. This shift in carbon and electron flow has been widely documented using carbon monoxide gassing in C. acetobutylicum [49] and 
C. pasteurianum [27], which also results in inhibition of the hydrogenase system. While we observed higher levels of butyrate and ethanol, both NADH-consuming pathways, the butanol pathway was only slightly stimulated, suggesting that excess $\mathrm{NADH}$ formed from the ferredoxin:NAD ${ }^{+}$oxidoreductase enzyme was not utilized for production of butanol. Strikingly, acetate formation, which is not a redox pathway, was dramatically increased upon expression of hydA asRNA, exemplifying an unexpected shift in acid production. In total, combined acid production (acetate and butyrate) more than double in the hydA asRNA strain, suggesting that hydrogenase knockdown affects cellular energetics, as acetate and butyrate pathways result in ATP formation via substrate level phosphorylation. Indeed, the hydA knockdown strain exhibited a shorter cultivation time and increased biomass production (Table 2), which are consistent with a higher ATP yield. Finally, expression of hydA asRNA also exhibited an unexpected decline in 1,3-propanediol production, which ostensibly contrasts the presumed flow of electrons outlined above. Overall, however, we have observed substantial variability in 1,3-propanediol titer across fermentations conducted under seemingly identical conditions (data not shown), as 1,3-propanediol appears to be the most variable metabolite produced by $C$. pasteurianum. A similar lack of pathway control has been noted by others [3,4]. Therefore, the decreased production of 1,3-propanediol observed in this study may not represent a direct consequence of hydrogenase downregulation. Collectively, the findings unveiled in this study through downregulation of hydA underpin the complex and highly branched fermentative metabolism exhibited by $C$. pasteurianum and provide a groundwork for rational metabolic engineering of this important industrial bacterium.

\section{Conclusions}

In this work, we show that plasmid-based heterologous gene overexpression and asRNA-mediated gene downregulation are effective tools for altering gene expression in C. pasteurianum. The constitutive $f d x$ and $t h l$ transcriptional promoters characterized in this study should find use in future C. pasteurianum gene expression applications, including plasmid-based expression of non-native pathways and cellular activities, as well as overexpression of key $C$. pasteurianum genes. We also show that central fermentative metabolism in $C$. pasteurianum can be dramatically altered through expression of asRNA targeted to the primary hydrogenase mRNA. Our devised asRNA methodology should expand the available set of genetic tools towards metabolic engineering of $C$. pasteurianum, through systematic knockdown of undesirable and unproductive chromosomal genes and metabolic pathways.

\section{Acknowledgments}

This work was supported in part by the Natural Sciences and Engineering Research Council (NSERC) and the Canada Research Chair (CRC) program of Canada.

\section{Author Contributions}

Michael E. Pyne helped conceived of the study, participated in its design and coordination, carried out the experiments, and drafted the manuscript. Murray Moo-Young participated in the study design and coordination. Duane A. Chung and C. Perry Chou helped conceive of the study, participated in its design and coordination, and helped to draft the manuscript. All authors read and approved the final manuscript. 


\section{Conflicts of Interest}

Duane A. Chung is a founder and employee of Algaeneers Inc., at which Michael E. Pyne has also been employed. Algaeneers Inc. has a financial interest in production of biofuels using microorganisms.

\section{References}

1. Ahn, J.H.; Sang, B.I.; Urn, Y. Butanol production from thin stillage using Clostridium pasteurianum. Bioresour. Technol. 2011, 102, 4934-4937.

2. Ensen, T.O.; Kvist, T.; Mikkelsen, M.J.; Christensen, P.V.; Westermann, P. Fermentation of crude glycerol from biodiesel production by Clostridium pasteurianum. J. Ind. Microbiol. Biotechnol. 2012, 39, 709-717.

3. Taconi, K.A.; Venkataramanan, K.P.; Johnson, D.T. Growth and solvent production by Clostridium pasteurianum ATCC (R) 6013 (Tm) utilizing biodiesel-derived crude glycerol as the sole carbon source. Environ. Prog. Sustain. Energy 2009, 28, 100-110.

4. Biebl, H. Fermentation of glycerol by Clostridium pasteurianum-Batch and continuous culture studies. J. Ind. Microbiol. Biotechnol. 2001, 27, 18-26.

5. Lee, S.Y.; Park, J.H.; Jang, S.H.; Nielsen, L.K.; Kim, J.; Jung, K.S. Fermentative butanol production by Clostridia. Biotechnol. Bioeng. 2008, 101, 209-228.

6. Pfromm, P.H.; Amanor-Boadu, V.; Nelson, R.; Vadlani, P.; Madl, R. Bio-butanol vs. bio-ethanol: A technical and economic assessment for corn and switchgrass fermented by yeast or Clostridium acetobutylicum. Biomass Bioenergy 2010, 34, 515-524.

7. Swana, J.; Yang, Y.; Behnam, M.; Thompson, R. An analysis of net energy production and feedstock availability for biobutanol and bioethanol. Bioresour. Technol. 2011, 102, 2112-2117.

8. Johnson, D.T.; Taconi, K.A. The glycerin glut: Options for the value-added conversion of crude glycerol resulting from biodiesel production. Environ. Prog. 2007, 26, 338-348.

9. Yazdani, S.S.; Gonzalez, R. Anaerobic fermentation of glycerol: A path to economic viability for the biofuels industry. Curr. Opin. Biotechnol. 2007, 18, 213-219.

10. Van Haandel, A.C.; Catunda, P.F.C. Profitability increase of alcohol distilleries by the rational use of byproducts. Water Sci. Technol. 1994, 29, 117-124.

11. Johnston, M.; Holloway, T. A global comparison of national biodiesel production potentials. Environ. Sci. Technol. 2007, 41, 7967-7973.

12. Pyne, M.E.; Moo-Young, M.; Chung, D.A.; Chou, C.P. Development of an electrotransformation protocol for genetic manipulation of Clostridium pasteurianum. Biotechnol. Biofuels 2013, 6, 50.

13. Pyne, M.E.; Moo-Young, M.; Chung, D.A.; Chou, C.P. Expansion of the genetic toolkit for metabolic engineering of Clostridium pasteurianum: Chromosomal gene disruption of the endogenous cpaai restriction enzyme. Biotechnol. Biofuels 2014, 7, 163.

14. Kolek, J.; Sedláŕ, K.; Provazník, I.; Patáková, P. Draft genome sequence of Clostridium pasteurianum NRRL B-598, a potential butanol or hydrogen producer. Genome Announc. 2014, 2, doi:10.1128/genomeA.00192-14. 
15. Pyne, M.E.; Utturkar, S.; Brown, S.D.; Moo-Young, M.; Chung, D.A.; Chou, C.P. Improved draft genome sequence of Clostridium pasteurianum strain ATCC 6013 (DSM 525) using a hybrid next-generation sequencing approach. Genome Announc. 2014, 2, e00790-14.

16. Rappert, S.; Song, L.; Sabra, W.; Wang, W.; Zeng, A.P. Draft genome sequence of type strain Clostridium pasteurianum DSM 525 (ATCC 6013), a promising producer of chemicals and fuels. Genome Announc. 2013, 1, doi:10.1128/genomeA.00232-12.

17. Poehlein, A.; Grosse-Honebrink, A.; Zhang, Y.; Minton, N.P.; Daniel, R. Complete genome sequence of the nitrogen-fixing and solvent-producing Clostridium pasteurianum DSM 525. Genome Announc. 2015, 3, doi:10.1128/genomeA.01591-14.

18. Rotta, C.; Poehlein, A.; Schwarz, K.; Mcclure, P.; Daniel, R.; Minton, N.P. Closed genome sequence of Clostridium pasteurianum ATCC 6013. Genome Announc. 2015, 3, doi:10.1128/genomeA.01596-14.

19. Pyne, M.E.; Liu, X.; Moo-Young, M.; Chung, D.A.; Chou, C.P. Genomic-directed analysis of prophage excision, host defence systems, and central fermentative metabolism in Clostridium pasteurianum. unpublished work, 2015.

20. Pyne, M.E.; Bruder, M.; Moo-Young, M.; Chung, D.A.; Chou, C.P. Technical guide for genetic advancement of underdeveloped and intractable Clostridium. Biotechnol. Adv. 2014, 32, 623-641.

21. Papoutsakis, E.T. Engineering solventogenic Clostridia. Curr. Opin. Biotechnol. 2008, 19, 420-429.

22. Song, C.W.; Lee, J.; Lee, S.Y. Genome engineering and gene expression control for bacterial strain development. Biotechnol. J. 2015, 10, 56-68.

23. Cooksley, C.M.; Zhang, Y.; Wang, H.Z.; Redl, S.; Winzer, K.; Minton, N.P. Targeted mutagenesis of the Clostridium acetobutylicum acetone-butanol-ethanol fermentation pathway. Metab. Eng. 2012, 14, 630-641.

24. Desai, R.P.; Papoutsakis, E.T. Antisense RNA strategies for metabolic engineering of Clostridium acetobutylicum. Appl. Environ. Microbiol. 1999, 65, 936-945.

25. Tummala, S.B.; Welker, N.E.; Papoutsakis, E.T. Design of antisense rna constructs for downregulation of the acetone formation pathway of Clostridium acetobutylicum. J. Bacteriol. 2003, 185, 1923-1934.

26. Gheshlaghi, R.; Scharer, J.M.; Moo-Young, M.; Chou, C.P. Metabolic pathways of Clostridia for producing butanol. Biotechnol. Adv. 2009, 27, 764-781.

27. Dabrock, B.; Bahl, H.; Gottschalk, G. Parameters affecting solvent production by Clostridium pasteurianum. Appl. Environ. Microbiol. 1992, 58, 1233-1239.

28. Simons, R.; Kleckner, N. Biological regulation by antisense RNA in prokaryotes. Annu. Rev. Genet. 1988, 22, 567-600.

29. Wagner, E.G.H.; Simons, R.W. Antisense RNA control in bacteria, phages, and plasmids. Annu. Rev. Microbiol. 1994, 48, 713-742.

30. Tummala, S.B.; Junne, S.G.; Papoutsakis, E.T. Antisense RNA downregulation of coenzyme a transferase combined with alcohol-aldehyde dehydrogenase overexpression leads to predominantly alcohologenic Clostridium acetobutylicum fermentations. J. Bacteriol. 2003, 185, 3644-3653.

31. Perret, S.; Maamar, H.; Belaich, J.P.; Tardif, C. Use of antisense rna to modify the composition of cellulosomes produced by Clostridium cellulolyticum. Mol. Microbiol. 2004, 51, 599-607.

32. Nakayama, S.I.; Kosaka, T.; Hirakawa, H.; Matsuura, K.; Yoshino, S.; Furukawa, K. Metabolic engineering for solvent productivity by downregulation of the hydrogenase gene cluster Hupcba 
in Clostridium saccharoperbutylacetonicum Strain N1-4. Appl. Microbiol. Biotechnol. 2008, 78, 483-493.

33. Liyanage, H.; Young, M.; Kashket, E.R. Butanol tolerance of Clostridium Beijerinckii NCIMB 8052 associated with down-regulation of GLDA by antisense RNA. J. Mol. Microbiol. Biotechnol. 2000, 2, 87-93.

34. Sillers, R.; A-Hinai, M.A.; Papoutsakis, E.T. Aldehyde-alcohol dehydrogenase and/or thiolase overexpression coupled with coa transferase downregulation lead to higher alcohol titers and selectivity in Clostridium acetobutylicum fermentations. Biotechnol. Bioeng. 2009, 102, 38-49.

35. Tummala, S.B.; Welker, N.E.; Papoutsakis, E.T. Development and characterization of a gene expression reporter system for Clostridium acetobutylicum ATCC 824. Appl. Environ. Microbiol. 1999, 65, 3793-3799.

36. Heap, J.T.; Pennington, O.J.; Cartman, S.T.; Minton, N.P. A modular system for Clostridium shuttle plasmids. J. Microbiol. Methods 2009, 78, 79-85.

37. Bruder, M.; Moo-Young, M.; Chung, D.A.; Chou, C.P. Elimination of carbon catabolite repression in Clostridium acetobutylicum - A journey toward simultaneous use of xylose and glucose. Appl. Microbiol. Biotechnol. 2015, 99, 7579-7588.

38. Sambrook, J.; Fritsch, E.F.; Maniatis, T. Molecular Cloning: A Laboratory Manual, 2nd ed.; Cold Spring Harbor Press: Cold Spring Harbor, NY, USA, 1989.

39. Miller, J.H. Experiments in Molecular Genetics; Gold Spring Harbor Laboratory: Gold Spring Harbor, NY, USA, 1972.

40. Moon, C.; Lee, C.H.; Sang, B.I.; Um, Y. Optimization of medium compositions favoring butanol and 1,3-propanediol production from glycerol by Clostridium pasteurianum. Bioresour. Technol. 2011, 102, 10561-10568.

41. Graves, M.; Rabinowitz, J. In vivo and in vitro transcription of the Clostridium pasteurianum ferredoxin gene. evidence for "extended" promoter elements in gram-positive organisms. J. Biol. Chem. 1986, 261, 11409-11415.

42. Meng, Y.; Li, J.L. Cloning, expression and characterization of a thiolase gene from Clostridium pasteurianum. Biotechnol. Lett. 2006, 28, 1227-1232.

43. Guedon, E.; Desvaux, M.; Petitdemange, H. Improvement of cellulolytic properties of Clostridium cellulolyticum by metabolic engineering. Appl. Environ. Microbiol. 2002, 68, 53-58.

44. Heap, J.T.; Pennington, O.J.; Cartman, S.T.; Carter, G.P.; Minton, N.P. The clostron: A universal gene knock-out system for the genus Clostridium. J. Microbiol. Methods 2007, 70, 452-464.

45. Rabinowitz, J. Preparation and properties of clostridial ferredoxins. Methods Enzymol. 1971, 24, 431-446.

46. Heyndrickx, M.; Devos, P.; Deley, J. Fermentation characteristics of Clostridium pasteurianum LMG 3285 grown on glucose and mannitol. J. Appl. Bacteriol. 1991, 70, 52-58.

47. Higashide, W.; Li, Y.C.; Yang, Y.F.; Liao, J.C. Metabolic engineering of Clostridium cellulolyticum for production of isobutanol from cellulose. Appl. Environ. Microbiol. 2011, 77, 2727-2733.

48. Mermelstein, L.D.; Welker, N.E.; Bennett, G.N.; Papoutsakis, E.T. Expression of cloned homologous fermentative genes in Clostridium acetobutylicum ATCC 824. Bio-Technology 1992, 10, 190-195. 
49. Kim, B.H.; Bellows, P.; Datta, R.; Zeikus, J.G. Control of carbon and electron flow in Clostridium acetobutylicum fermentations-Utilization of carbon monoxide to inhibit hydrogen production and to enhance butanol yields. Appl. Environ. Microbiol. 1984, 48, 764-770.

(C) 2015 by the authors; licensee MDPI, Basel, Switzerland. This article is an open access article distributed under the terms and conditions of the Creative Commons Attribution license (http://creativecommons.org/licenses/by/4.0/). 